\title{
INFLUENCE OF CREATINE KINASE ON C-REACTIVE PROTEIN IN MUSCLE ADAPTATION
}

\author{
INFLUÊNCIA DA CREATINA QUINASE SOBREA PROTEÍNA C-REATIVA NA ADAPTAÇÃO MUSCULAR
}

INFLUENCIA DELA CREATINA QUINASA SOBRE LA PROTEÍNA C-REACTIVA EN LAADAPTACIÓN MUSCULAR

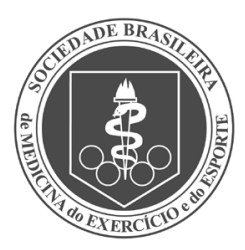

Original Article

Artigo Original

Artículo Original
Luís Ângelo Macêdo Santiago' (Physiotherapist)

Lídio Gonçalves Lima Neto² (Pharmacist and Biochemist) Guilherme Borges Pereira ${ }^{3}$ (Physiotherapist)

Richard Diego Leite ${ }^{4}$

(Physical Education Professional)

Cristiano Teixeira Mostarda ${ }^{5}$ (Physical Education Professional)

Francisco Navarro 5

(Physical Education Professional)

1. Universidade Federal do Maranhão, Department of Medicine, Pinheiro, MA, Brazil. 2. Universidade Ceuma, Laboratório de Imunologia e Microbiologia de Infecções Respiratórias, São Luís, MA, Brazil.

3. Universidade Federal de São Carlos, Centro de Ciências Biológicas e da Saúde, Department of Physiological Sciences,

São Carlos, SP, Brazil.

4. Universidade Federal do Espírito Santo, Department of Physical Education, Vitória, ES, Brazil. 5. Universidade Federal do Maranhão, Department of Physical Education, São Luís, MA, Brazil.

\section{Correspondence:}

Luís Ângelo Macêdo Santiago. Universidade Federal do Maranhão, Department of Medicine. Avenida dos Portugueses, 1.966, Bacanga, São Luís, MA, Brazil. 65080-805. luisangelomacedo@gmail.com

\begin{abstract}
Introduction: Aging is a natural process and marked by changes and adaptations of both a biological and physiological nature. As regards adaptations, there are numerous works that address these responses following various types of training programs. Resistance training (RT) can be assessed by biochemical parameters such as creatine kinase (CK), which is a major marker of stress in the skeletal muscles. C-reactive protein (CRP) is a biochemical marker used to assess damage to the cardiac muscles. Objective: To evaluate the influence of CK on CRP in elderly female subjects undergoing RT. Methods: An experimental study was carried out with 10 elderly women (61 \pm 1.8 years). Peripheral venous blood was collected for the CK and CRP analysis both before and 24 hours after 8 weeks of RT. Anthropometric measurements involved BMI (Body Mass Index), WHR (waist-to-hip ratio) and body composition. The RT involved combined series - Bi-Set. For statistical analysis, the Shapiro-Wilk normality test was conducted first and presented $p>0.05$, confirming the use of parametric tests. Group variables were presented as mean and standard deviation. To compare the load-dependent samples, the repeated measures one-way ANOVA was performed first, followed by Tukey's post hoc test. For CK and CRP variables, we conducted the paired Student's t-test for the timepoints pre- and post-eight weeks of RT along with the one-way ANOVA test, also conducting Tukey's post-test when necessary. The level of significance was set at $p \leq 0.05$. Results: There was a statistically significant decrease in both serum CK and CRP, which indicated a reduction of $73.14 \%$ and $75 \%$, respectively. Conclusion: Long-term RT promoted influences among biomarkers assessed through skeletal muscle (CK) and cardiac muscle (CRP) damage, determining adaptation and muscle remodeling in any age group. Level of evidence II, Investigation of treatment results.
\end{abstract}

Keywords: Creatine kinase; C-reactive protein; Myalgia; Aged.

\section{RESUMO}

Introdução: O envelhecimento é um processo natural e marcado por mudanças e adaptações, tanto biológicas quanto fisiológicas. Com relação às adaptações, existem inúmeros trabalhos que abordam essas respostas decorrente a vários tipos de treinamento. O treinamento resistido (TR) pode ser avaliado por parâmetros bioquímicos, como a creatina quinase (CK), que éum grande marcador de estresse da musculatura esquelética. A proteína C-reativa (PCR) éum marcador bioquímico utilizado para avaliar o dano no sistema muscular cardíaco. Objetivo: Avaliar a influência da CK sob a PCR em idosas em TR. Métodos: Estudo do tipo experimental com dez idosas (61 $\pm 1,8$ anos). As análises de CK e PCR foram coletadas em sangue venoso periférico antes e 24 horas após as 8 semanas de TR. Medidas antropométricas foram realizadas: índice de massa corporal (IMC), relação da cintura e o quadril (RCQ) e composição corporal. O TR foi realizado por série combinada (Bi-Set). Para análise estatística, primeiramente foi realizado o teste de normalidade de Shapiro-Wilk, apresentando $p>0,05$ ) e comprovando a utilização de testes paramétricos. As variáveis do grupo foram apresentadas como média e desvio padrão. Para comparação das amostras dependentes de evolução das cargas foi realizado a ANOVA one-way pareada para medidas repetidas, seguida de pós-teste de Tukey. Para variáveis de CK e PCR, foi realizado teste t de Student pareado para os momentos pré e pós-8 semanas de TR, assim como o ANOVA one-way e, quando necessário, o pós-teste de Tukey. O nível de significância adotado foi de $p \leq 0,05$. Resultados: Houve diminuição estatisticamente significativa, tanto para as concentrações séricas de $C K$, quanto para PCR, o que indicou redução de $73,14 \%$ e 75\%, respectivamente. Conclusão: O TR de longa duração promoveu influências entre biomarcadores avaliados por meio do dano do músculo esquelético (CK) e dano do músculo cardíaco (PCR), determinando adaptação e remodelamento muscular em qualquer faixa etária. Nível de evidência Il; Investigação dos resultados do tratamento.

Descritores: Creatina quinase; Proteína C-reativa; Mialgia; Idoso.

\section{RESUMEN}

Introducción: El envejecimiento es un proceso naturaly marcado por cambios y adaptaciones, tanto biológicas como fisiológicas. Con respecto a las adaptaciones, existen innumerables trabajos que abordan esas respuestas derivadas de varios tipos de entrenamiento. El Entrenamiento Resistido (ER) puede ser evaluado por parámetros bioquímicos, como la creatina quinasa (CK) quees un gran marcador de estrés de la musculatura esquelética. La proteína C-reactiva $(P C R)$ es un marcador bioquímico utilizado para evaluar el daño en el sistema muscular cardíaco. Objetivo: Evaluar 
la influencia de la CK bajo la PCR en ancianas en ER. Métodos: Estudio de tipo experimental con 10 ancianas (61 \pm 1,8 años). Los análisis de CK y PCR fueron recolectados en sangre venosa periférica antes y 24 horas después de las 8 semanas de ER. Se realizaron mediciones antropométricas: IMC (Índice de Masa Corporal), RCC (Relación Cintura I Cadera) y Composición Corporal. El ER fue realizado por Serie Combinada (Bi-Set). Para análisis estadístico, primero se realizó la prueba de normalidad de Shapiro-Wilk presentando p>0,05 y comprobando el uso de pruebas paramétricas. Las variables del grupo se mostraron como promedio y desviación estándar. Para comparación de las muestras dependientes de evolución de las cargas se realizó el Test one-way ANOVA pareado para medidas repetidas, seguido de post-test de Tukey. Para variables de CKy PCR se realizó el Test t de Student pareado para los momentos pre y post ocho semanas de ER, así como el ANOVA one-way y cuando necesario, el post-test de Tukey. El nivel de significancia adoptado fue de $p \leq 0,05$. Resultados: Hubo disminución estadísticamente significativa, tanto para las concentraciones séricas de CK, como para PCR, lo que indicó reducción del 73,14\% y el 75\%, respectivamente. Conclusión: El ER de larga duración promovió influencias entre biomarcadores evaluados a través del daño del músculo esquelético (CK) y daño del músculo cardíaco (PCR) determinando adaptación y remodelación muscular en cualquier grupo de edad. Nivel de evidencia ll; Investigación de los resultados del tratamiento.

Descriptores: Creatina quinasa; Proteína C-reactiva; Mialgia; Anciano.

\section{INTRODUCTION}

Aging is a natural process and marked by important changes in the body, with impairment in its mechanisms of adaptation, where they vary from individual to individual and depend on several factors, among them, the lifestyle that this individual follows interferes in the health / disease. ${ }^{1}$ In this adaptation process, both biological and physiological changes occur as a result of aging, with loss of biological repair capacity, including conditions that include weakness or deterioration of the body, influencing the appearance of various pathologies. ${ }^{1,2}$ Toigo and Boutellier ${ }^{3}$ reports that the human organism has a great ability to adapt to various types of training, regardless of the age group. It concludes that these adaptations continue to occur as a consequence of a vast amount of training-related information.

Amongst several types of training, resistance training (RT) is a widely used method to improve the physical performance of the general population.

For this, it is necessary to apply progressive overloads to the musculoskeletal system during training sessions, in order to provoke disturbances of homeostasis causing a stress to the organism.,4 For Antunes-Neto et al ${ }^{5}$, these disorders caused by TR can be evaluated by biochemical parameters, among them creatine kinase (CK) being a great marker of skeletal muscle stress, resulting from the training performed, as well as a factor of control and monitoring of the training load. In this way, the more intense and prolonged the exercise, the greater the amount of muscular microleaders allowing the exit of this enzyme to the extracellular environment. ${ }^{6}$ Thus, the monitoring and behavior of CK concentrations has been increasingly used to determine the magnitude of the physical requirement imposed on the skeletal muscle system, as well as its adaptation to training.

While CK is the biochemical marker most commonly used in the literature to evaluate lesions caused in skeletal muscle cells, C-reactive protein (CRP) is a biochemical marker used to assess damage to the cardiac muscle system, where Mavros et al. ${ }^{7}$ Santos et al., ${ }^{8}$ reported having an important role in the inflammation process of the cardiac muscle, since it is considered the main acute phase protein and synthesized from the influence of IL-6 under the hepatic system. Therefore, this marker has an important function, since it constitutes an inflammatory marker considered a strong independent predictor of risk for cardiovascular event and death caused by cardiovascular diseases.

Studies that measure the influence of markers of skeletal muscle modulation (CK) under the reduction of cardiac muscle tissue marker (CRP) through resistance training in the elderly are less common in the literature. Based on this, the study is justified in delving deeper into the subject in order to know better in what way these mechanisms happen.

\section{METHODS}

The research was characterized by the experimental type, where initially 11 elderly women participated in the research, one of which did not complete the research due to health reasons, ending with (n $=10)(61 \pm 1.8)$. The experimental study was approved by the National Commission for Research Ethics (CONEP) for experimental research projects involving human beings, under the opinion of CAEE No. 10863313.2.1001.5084, opinion No. 372453/2013. Initially, the elderly were contacted by the University of the Third Age - UNITI, after prior contact the participants signed the Informed Consent Term (TCLE). Inclusion criteria were: Accept voluntary participation; Women aged between 60 and 70 years; Not having participated in any structured program and accompanied by TR in the last six months; Non-smoking participants who influence the performance imposed by the Training; According to WHO (1998), the participants had no body mass index (BMI) and waist / hip ratio $\left(\mathrm{BMI}=<30 \mathrm{~kg} / \mathrm{m}^{2}\right.$ and $\left.\mathrm{WHR}=<1.00\right)$. On the other hand, for exclusion criteria, participants with hypertension and diabetes mellitus decompensated in a directed anamnesis, participants with changes in total numbers of Leukocytes that indicate acute infectious processes in the biochemical analysis of the leukogram, participants who had frequency less than $85 \%$ of the sessions during the eight weeks of the training program.

The RT protocol was based on a critical analysis following the databases of the following authors, ${ }^{8-11}$ being thus performed on bodybuilders for a total period of eight weeks. The type of training was by BI-SET Combination Series, which consists of performing two exercises without time interval for distinct muscle groups, Lower Limbs (LIM) and Upper Limbs (LIM) and after their completion, there is an interval for that the second passage is made, after repeating the interval, the third passage begins.

Weekly Frequency: Three times a week and included eight exercises divided into Upper and Lower Limbs: Sitting Leg Press, Sitting Supine, Knee Extension, Pulley Back, Knee Flexion Lying, Flexing Elbows on the Low Pulley,Extension of elbows in the pulley.

Number of repetitions: It was performed through the Repetition Zone prioritizing muscular hypertrophy, (8-12 repetitions). To control the training protocol, an individualized program card containing all exercises of the training program was used. In order to control and increase the intensity (load-kg), two criteria were adopted: 1) To determine the load increase according to the intensity of effort reported by the participants, the Effort Perception Scale (BORG) was used; 2) All participants performed their RT program within a maximum repetition range of 8 to 12 repetitions, so that 
whenever participants exceeded the limits of this zone, a new increase in load occurred to keep them within the zone established.

Increase of intensity (load-kg): two criteria were adopted: 1) To determine the load increase according to the intensity of effort reported by the participants, the Effort Perception Scale (BORG) was used; 2) All participants performed their RT program within a maximum repetition zone of eight to 12 repetitions, so that every time the participants exceeded the limits of this zone, a new increase in load occurred to keep it within the zone again established.

Time interval and duration of sessions: One minute rest was established between the segments worked and the average duration of 50 minutes per session.

Speed performed in the execution of the exercises: The duration speed of three seconds was respected for each movement, being 1.5 seconds for the concentric phase and 1.5 seconds for the eccentric phase, controlled by visual and verbal commands for standardization of the angulations of movement. ${ }^{9}$

Time of daily sessions: Average duration of 50 minutes per session.

Initially, the participants performed a week of familiarization with the TR, composed of two sets of 15 submaximal repetitions with the purpose of knowing the exercises and their respective executions and promoting neuromuscular adaptations, thus avoiding the excessive onset of Late Muscle Pain (DMIT) to then start TR. Before and after all the training sessions, participants waited in the room for 5 minutes to measure their blood pressure to control vital patterns. The TR program was supervised and supervised by a Physiotherapist and two Physical Education Professionals.

In order to control anthropometric parameters and BMI, the following variables were measured: Body mass, height and BMI calculation were measured using the digital scale (Welmy ${ }^{\oplus}$-W300, Brazil), with a maximum capacity of $300 \mathrm{~kg}$. Waist and hip circumferences were then measured on a measuring tape of the brand (Waist Fit ${ }^{\circledR}$, Brazil) in order to obtain data from WHR.

For the body composition, all the participants, prior to the measurements, were instructed not to feed two hours before the test, to not drink alcohol 24 hours before the test, not to drink alcoholic beverage and not to perform physical exercise 24 hours before the test, monitor fluid intake, and urinate 30 minutes prior to evaluation. The participants were then asked to lie down on the stretcher to fix the electrodes at the predetermined points and sanitize them with $70 \%$ liquid alcohol. The emitting electrodes were positioned at the following sites: the right hand dorsal surface near the metacarpophalangeal joint, the distal region of the transverse arch of the upper right foot, and the sensing electrodes were positioned in the posterior prominence of the distal radius of the right wrist and the other between the medial and lateral malleolus of the right ankle. This procedure was performed by means of a four-pole electric bioimpedance (Maltron BF-906 Body Fat Analyzer, Brazil).

The blood samples were taken by a trained phlebotomist, following the biosafety norms recommended by NR32, and they occurred in two moments: Pre (antecedent to TR) and Post (24 hours after the last resistance training), with the corresponding time interval to eight weeks between the two collections. The elderly women were instructed to attend the site in the morning and in a maximum fast of 12 hours. Blood samples were collected under vacuum with a volume of approximately $9 \mathrm{~mL}$ in a dry tube containing $5 \mathrm{~mL}$ of a clot-separating gel (Vacuette). After the blood sample was collected, the tubes were labeled and transported in hermetically sealed thermal boxes and sent to the Clinical Analysis Laboratory to be analyzed for Creatine Kinase (CK) and C-Reactive Protein (PCR).

\section{Statistical analysis}

Statistical analysis was performed using GraphPad Prism 6.0 software. First, the Shapiro-Wilk normality test was performed, presenting one ( $p>0.05)$ proving the use of parametric tests. The variables of the group were presented as mean and standard deviation. To compare the load dependent samples, the One Way Test - ANOVA - paired for repeated measurements was performed, followed by Tukey post-test. For CK and PCR variables, the paired Student's t test was performed for the pre and post eight weeks of RT, as well as the One Way RM-ANOVA test and, when necessary, Tukey's post-test. The level of significance was set at $p<0.05$.

\section{RESULTS}

The sample was initially composed of 11 participants and completed after eight weeks with 10 participants. One obtained frequency less than $85 \%$ of the training sessions and was excluded. The characterization of the final sample can be seen in Table 1.

To control the evolution of the training load in the first, 4th and 8th weeks, the ANOVA test was performed for paired samples, followed by the Tukey post-test, showing a progression in their loads and in their respective exercises, showing a significant difference between all ( $p=$ $0.01{ }^{*}$ ), Table 2 .

For the data of the serum concentration of CK the Student t test was used. Therefore, there was a statistically significant decrease when comparing the Pre 100.9 $\pm 45.80 \mathrm{U} / \mathrm{L}$ moment with the Post $27.1 \pm 18.11$ $U / L(p<0.0001 *)$ moment, which represents a decrease of $73.14 \%$ in the serum concentration of CK shown in Figure 1.

For the serum concentrations of PCR the Student's t-test was also used. We observed a statistically significant decrease when comparing the pre-dose $2.24 \pm 1.43 \mathrm{mg} / \mathrm{L}$ with the post-dose $0.56 \pm 0.41 \mathrm{mg} / \mathrm{L}$ ( $p$ $<0.002 *$ ), representing a $75 \%$ decrease in serum concentration of CRP shown in Figure 2.

The serum concentrations of CK and PCR for the ANOVA test. They are presented in Figure 3. We observed a statistically significant decrease between the Pre and Posttraining moments for both serum concentrations.

Table 1. Sample Characteristics.

\begin{tabular}{c|c}
\hline Variable & $\mathbf{n}=\mathbf{1 0}$ \\
\hline Age (years) & $61 \pm 1,8$ \\
\hline Height (m) & $1,54 \pm 0,01$ \\
\hline Body Mass (kg) & $68,08 \pm 6,85$ \\
\hline Massa Gorda (kg) & $27,13 \pm 4,39$ \\
\hline Lean Mass percentage (\%) & $60,45 \pm 2,36$ \\
\hline Fat percentage (\%) & $39,55 \pm 3,14$ \\
\hline BMl (Kg /m $\left.{ }^{2}\right)$ & $28,74 \pm 2,64$ \\
\hline WHR (cm) & $0,83 \pm 0,06$
\end{tabular}

Data are presented as mean \pm standard deviation. BMI: Body Mass Index; WHR: Waist-to-Hip Ratio.

Table 2. Evolution of training load in first, fourth, and 8th weeks of RT.

\begin{tabular}{c|c|c|c|c|c}
\hline \multirow{2}{*}{ Exercises } & \multicolumn{5}{|c}{ RT (n= 10) } \\
\cline { 2 - 6 } & $\mathbf{1}^{\text {a } \text { week }}$ & $\mathbf{4}^{\text {a } \text { week }}$ & $\mathbf{8}^{\text {a } \text { week }}$ & $\begin{array}{c}\text { Effect } \\
\text { size }(\boldsymbol{\Delta})\end{array}$ & $\mathbf{p}$ Value \\
\hline Seated Leg Press (Kg) & $20.7 \pm 3.8$ & $33.6 \pm 1.1^{*}$ & $45.48 \pm 1.4^{*+}$ & 6.3 & 0.0001 \\
\hline $\begin{array}{c}\text { Elbow Flexion } \\
\text { (Low Pulley) (Kg) }\end{array}$ & $9.0 \pm 1.8$ & $13.8 \pm 0.3^{*}$ & $17.83 \pm 0.4^{*+}$ & 4.8 & 0.0001 \\
\hline Knee Extension (Kg) & $9.9 \pm 0.5$ & $18.4 \pm 0.6^{*}$ & $25.90 \pm 0.8^{*+}$ & 28.0 & 0.0001 \\
\hline Supine Seated (Kg) & $7.1 \pm 0.3$ & $13.8 \pm 0.4^{*}$ & $17.96 \pm 0.7^{*+}$ & 29.2 & 0.0001 \\
\hline Lying Knee Flexion (Kg) & $7.9 \pm 0.4$ & $15.5 \pm 2.0^{*}$ & $17.09 \pm 0.5^{*}$ & 22.1 & 0.0001 \\
\hline Pulley (Back) (Kg) & $13.2 \pm 0.5$ & $21.9 \pm 0.4^{*}$ & $27.03 \pm 0.5^{*+}$ & 26.4 & 0.0001 \\
\hline $\begin{array}{c}\text { Plantar Flexion } \\
\text { (Seated Leg Press) (Kg) }\end{array}$ & $20.0 \pm 0.7$ & $33.38 \pm 0.9^{*}$ & $43.56 \pm 1.2^{*+}$ & 30.9 & 0.0001 \\
\hline $\begin{array}{c}\text { Elbow Extension } \\
\text { (Pulley) (Kg) }\end{array}$ & $8.6 \pm 0.6$ & $16.42 \pm 0.4^{*}$ & $20.20 \pm 0.4^{*+}$ & 19.0 & 0.0001 \\
\hline
\end{tabular}

Data presented as mean \pm standard deviation. One-way ANOVA test followed by Tukey's post-test. * Statistically significant difference $(p<0.05)$ compared to first week. † Statistically significant difference $(p<0.05)$ compared to fourth week. $\Delta$ Effect size measures on the evolution of training load among the analyzed weeks. RT: resistance training. 


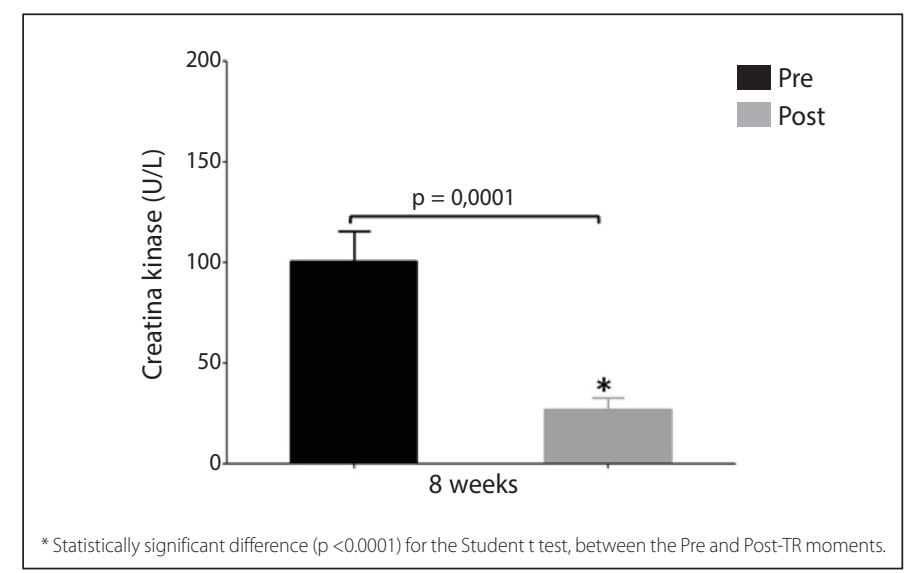

Figure 1. Data presented of CK in the Pre and Post moments $(n=10)$.

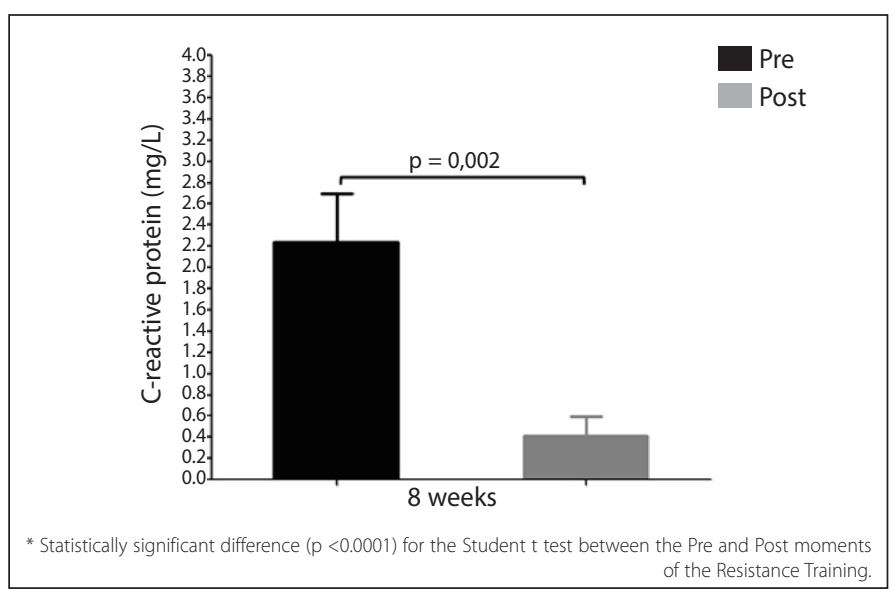

Figure 2. Data presented of PCR in the Pre and Post moments $(n=10)$.

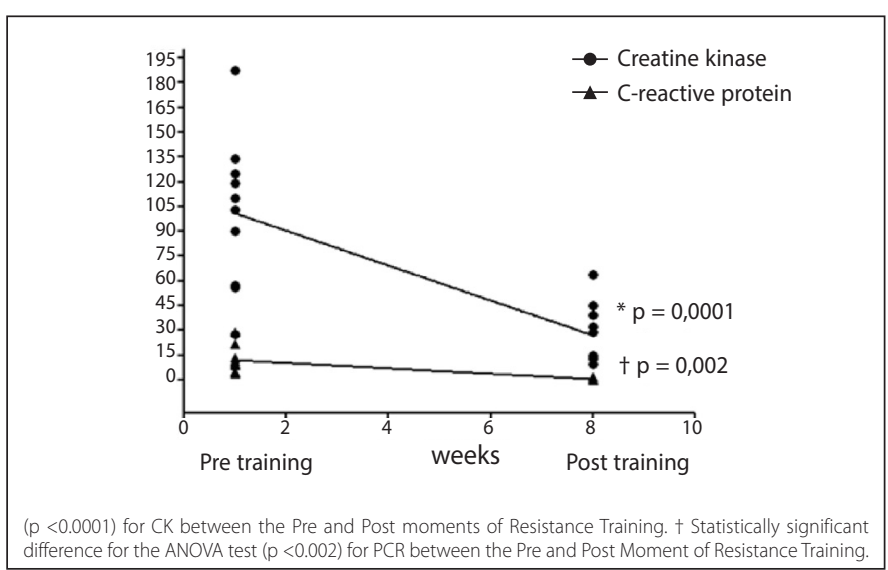

Figure 3. CK and PCR data $(n=10)$.

\section{DISCUSSION}

The objective of the study was to understand the events that influence Creatine Kinase (CK) in the modulation of C-reactive protein (CRP) inflammatory markers in the elderly through Resistance Training over eight weeks. The understanding of the findings allows us to observe a direct relationship between skeletal muscle adaptation assessed by CK and reduction of cardiac muscle injury marker through CRP. In this way, the muscular adaptation measured by the reduction of CK, induced the reduction of serum concentrations of CRP after eight weeks of resistance training. Thus, it can be suggested that the resistance training routine caused in the elderly in the long term influenced the kinetics of CK removal, in addition to influencing the reduction of biochemical parameters of CRP, unlike other studies in which the parameters were separately annualized without a strong relationship between the two.

These biochemical markers (CK and PCR) have great relationship when analyzed together. Antunes-Neto et al, ${ }_{1}^{5}$ report that creatine kinase (CK) is considered a great marker of skeletal muscle stress. In this way, the more intense and prolonged the exercise, the greater the amount of muscular microleadings allowing the exit of this enzyme to the extracellular environment increasing its plasma concentrations. ${ }^{6}$ Although extenuating physical exercises damage the skeletal muscle cells causing an increase in serum CK total, ${ }^{12,13}$ these same exercises increase the oxidative metabolism of the heart muscle by raising the concentrations of biomarkers in the blood plasma. ${ }^{14}$ Thus, vigorous physical exercise, besides increasing oxygen consumption, induces oxidative stress in the heart muscle, initiate a process of induction of acute phase protein release such as C-Reactive Protein (PCR). ${ }^{15}$

For Antunes-Neto et al., ${ }^{5}$ the mechanical stimulation applied in the muscle fiber during the long-term RT tends to regulate an increase in the tissue sensitivity of insulin and IGF-I (Insulin-like growth factor), which leads to the occurrence of hypertrophy muscular. These events are important for the muscular adaptation process, since the mechanical stimuli induced by the RT would stimulate the proliferation of myoblasts and the possible formation of new myofibers. ${ }^{16}$ Such mechanisms could be influenced by exercise stress, long-term hormonal responses and the need of tissue remodeling at the cellular level, thus, the high interactions between multiple hormones and receptors would provide a powerful adaptation mechanism in response to training, as a consequence of the reduction of biomarkers such as CK and CRP in blood plasma. ${ }^{17}$

Despite the numerous studies that focus on adaptive responses as a result of muscle strength training and biomarkers analyzed separately in blood plasma, there is little information about the mechanisms influencing CK under the reduction of CRP after long-term RT. In this context, we observe the study of Miranda-Vilela et al, ${ }_{1}^{18}$ that deduces a possible influence between these biomarkers. On the occasion, the authors evaluated 135 individuals of both sexes and different age groups (15-58 years) after a race training and investigated the influence of the CK polymorphisms (CKTaql) under the PCR gene (PCR G1059C), where both genes are induced by physical exercise and inflammation. In this perspective, the authors concluded that the polymorphism (CKTaql) significantly influenced the PCR results, reducing their parameters after training. The authors conclude that the results indicate that CK polymorphisms may influence the biomarker performance of RT-induced PCR inflammation

\section{CONCLUSION}

Concluding with our results and from the results of other authors, Long-term Resistance Training will promote, in addition to other factors, influences between biomarkers evaluated through skeletal muscle damage (CK) and cardiac muscle damage (CRP) by determining adaptation and muscle remodeling in any age group.

All authors declare no potential conflict of interest related to this article

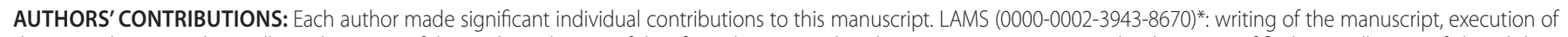
data, contribution to the intellectual concept of the study, evaluation of data from the statistical analysis, active participation in the discussion of findings, collection of clinical data, revision of the manuscript; LGLN (0000-0001-8299-5985)*: evaluation of data from the statistical analysis, active participation in the discussion of findings; GBP (0000-0002-5295-6229)*: active participation in the discussion of findings, collection of clinical data, revision of the manuscript; RDL (0000-0001-7937-6972)*: active participation in the discussion of findings, collection of clinical data, revision of the manuscript; CTM (0000-0002-1305-1697)*: evaluation of data from the statistical analysis, active participation in the discussion of findings; FN (0000-0002-2368-6020*: writing of the manuscript, execution of data, contribution to the intellectual concept of the study. All authors approved the final version of the manuscript. *ORCID (Open Researcher and Contributor ID). 


\section{REFERENCES}

1. Pappaléo NM. Gerontologia: a velhice e envelhecimento em uma visão globalizada, São Paulo: Atheneu; 1996.

2. Amaral PN, Pomatti DM, Fortes VL. Atividades físicas no envelhecimento humano: uma leitura sensível criativa. Rev Bras Cienc Envelhec Hum. 2007;4(1):18-27.

3. Toigo M, Boutellier U. New fundamental resistance exercise determinants o molecular and cellular muscle adaptations. Eur J Appl Physiol. 2006;97(6):643-63.

4. Willis LH, Slentz CA, Bateman LA, Shields AT, Piner LW, Bales CW, et al. Effects of aerobic and/ or resistance training on body mass and fat mass in overweight or obese adults. J Appl Physiol (1985). 2012;113(12):1831-7.

5. Antunes-Neto JM, Ferreira DC, Reis IC, Calvi RG, Rivera RJ. Manutenção de Microlesões celulares e respostas adaptativas a longo prazo no treinamento de força. Braz J Biomotr. 2007;1 (4):87-102.

6. Morandi RF, Coelho DB, de Melo MA, Silami-Garcia E. Cinética da creatina quinase em jogadores de futebol profissional em uma temporada competitiva. Rev Bras Cineantropom Desempenho Hum. 2011;13(3):189-94.

7. Mavros Y, Kay S, Simpson KA, Baker MK, Wang Y, Zhao RR, et al. Reductions in C-reactive protein in older adults with type 2 diabetes are related to improvements in body composition following a randomized controlled trial of resistance training. J Cachexia Sarcopenia Muscle. 2014;5(2):111-20.

8. Santos MG, Pegoraro M, Sandrini F, Macuco EC. Fatores de risco no desenvolvimento da aterosclerose na infância e adolescência. Arq Bras Cardiol. 2008;90(4):276-83.

9. Tidball JG. Inflammatory processes in muscle injury and repair. Am J Physiol Regul Integr Comp Physiol. 2005;288(2):345-53

10. Garber CE, Blissmer B, Deschenes MR, Franklin BA, Lamonte MJ, Lee IM. Quantity and Quality of Exercise for
Developing and Maintaining Cardiorespiratory, Musculoskeletal, and Neuromotor Fitness in Apparently Healthy Adults: Guidance for Prescribing Exercise. Am Coll Sports Med. 2011:1334-59.

11. Tibana RA, Pereira GB, Navalta, JW, Bottaro M, Prestes, J. Acute effects of resistance exercise on 24-h blood pressure in middle aged overweight and obese women. Int J Sports Med. 2013;34(5):460-4.

12. Brancaccio P, Maffulli N, Limongelli FM. Creatine kinase monitoring in sport medicine. Br Med Bull. 2007;81(82):209-30.

13. Plebani M. Skeletal muscle biomarkers: not new but still interesting diagnostic tools. Clin Chem Lab Med. 2010;48(6):745-6.

14. Ferreira F, Ferreira R, Duarte JA. Stress oxidativo e dano oxidativo muscular esquelético: influência do exercício agudo inabitual e do treino físico. Rev Port Cien Desp. 2007;7(2):257-75.

15. Sureda A, Tauler P, Aguiló A, Cases N, Fuentespina E, Córdova A, et al. Relation between oxidative stress markers and antioxidant endogenous defences during exhaustive exercise. Free Radicl Res. 2005;39(12):1317-24.

16. Vandenburgh HH, Karlisch P, Solerssi RL. Insulin and insulinlike growth factor-I stimulation of skeletal myofiber growth in vitro is enhanced 102 by mechanical activity. J Cell Biology. 1991;115(3):221-36

17. Antunes-Neto JM, Toyama MH, Carneiro EM, Boschero AC, Pereira-da-Silva L, Macedo DV. Circulating leukocyte heat shock protein 70 (HSP70) and oxidative stress markers in rats after a bout of exhaustive exercise. Stress. 2006;9(2):107-15.

18. Miranda-Vilela AL. Akimoto AK, Lordelo GS, Pereira LC, Grisolia CK, Klautau-Guimarães MN. Creatine kinase MM Taql and methylenetetrahydrofolate reductase C677T and A1298C gene polymorphisms influence exercise-induced C-reactive protein levels. Eur J Appyl Physiol. 2012;112(3):941-50. 